\title{
Corrosion Inhibition of Stainless Steel Alloys in Phosphoric Acid Solution
}

\author{
A.S. Ahmed, R.M. Abou Shahba, E.M. Attia, W.A.M. \\ Hussein and I.M. Ghayad* \\ Chemistry Department, Faculty of Science (For Girls), Al \\ Azhar University and ${ }^{*}$ Central Metallurgical Research and \\ Development Institute, Cairo, Egypt.
}

\begin{abstract}
THE CORROSION behavior of two stainless steel alloys in phosphoric acid solutions in the absence and in the presence of 3amino-1, 2, 4-triazole (AT),4-amino-5-mercapto-1, 2, 4-triazole (AMT) and sodium orthophosphate corrosion inhibitors was studied using open circuit potential and potentiodynamic polarization techniques. Open circuit potential measurements of the two stainless steel electrodes in different concentrations of $\mathrm{H}_{3} \mathrm{PO}_{4}$ showed that the rates of film thickening of the two electrodes are independent of the solution concentration. Potentiodynamic polarization curves showed that the increase of $\mathrm{Na}_{3} \mathrm{PO}_{4}$ concentration in $0.5 \mathrm{M} \mathrm{H}_{3} \mathrm{PO}_{4}$ brought changes in the $\mathrm{pH}$ of solutions in the range 1.7-10.7 and decreases the corrosion rate. Electrode type (II) has inhibition efficiency more than the electrode type (I). AT compound (3-amino-1,2,4-triazole) has proven to be efficient inhibitor for pitting corrosion of stainless steel in phosphoric acid solutions. The inhibition efficiency may be argued to the formation of a compact Fe-AT complex film on the electrode surface.
\end{abstract}

Stainless steel alloys are selected as engineering materials mainly because of their excellent corrosion resistance. Small amounts of chromium, about 5\%, add some corrosion resistnace to iron, but in order to make stainless steel, at least $12 \% \mathrm{Cr}$ is required. Addition of nickel to stainless steel improves their corrosion resistance in neutral or weakly oxidizing media ${ }^{(1,2)}$. Molybdenum forms a passive $\mathrm{MoO}_{2}$ film in the active region of stainless steels and hence decreases the active dissolution current ${ }^{(3)}$. In order to achieve improved pitting resistance, Mo content should be higher than $1 \%$. The best results are obtained for alloys with Mo content between $3 \%$ and $4 \%{ }^{(4)}$. Duplex and super duplex stainless steels are used in applications in media containing ions from the halogen family, mainly the chloride ion ${ }^{(5,6)}$ and have good sea water corrosion resistance ${ }^{(2,7)}$. The corrosion rate of some stainless steel alloys in industrial phosphoric acid increases with the increase of temperature. Alloys which contain chromium, molybdenum and nitrogen in sufficient quantities present the best behavior ${ }^{(8)}$.

Many authors have studied the corrosion and inhibition of stainless steels in acid solutions ${ }^{(9-14)}$. Organic compounds are used to inhibit corrosion of stainless

*E-mail: ighayad@yahoo.com 
steel alloys ${ }^{(15-21)}$. Among these compounds, heterocyclic substance containing nitrogen atoms, such as triazole-type compounds are considered excellent corrosion inhibitors for many metal and alloys in various aggressive media ${ }^{(22-25)}$.

The present work investigates the corrosion behavior of two stainless steel alloys in phosphoric acid solutions. The corrosion inhibition of the two alloys was also studied using sodium orthophosphate and amino triazole.

\section{Experimental}

Two electrodes of molybdenum alloyed stainless steel of special grades have been tested. Typical values of their chemical compositions are given in Table 1. Cylindrical electrodes with a working surface area of $0.68 \mathrm{~cm}^{2}$ were used. Electrodes were enclosed in a holder so that the only cross sectional area is exposed to the testing solution. Electrodes were ground with different size emery papers and polished with diamond paste $(1 \mu \mathrm{m})$ and finally were cleaned by bidistilled water and ethyl alcohol.

TABLE 1. Chemical composition of the two types of electrodes.

\begin{tabular}{|c|c|c|c|c|c|c|}
\hline \multirow{2}{*}{ Electrode Type } & \multicolumn{7}{|c|}{ Amount of Elements (wt \%) } \\
\cline { 2 - 7 } & $\mathbf{S i}$ & $\mathbf{C r}$ & $\mathbf{M n}$ & $\mathbf{F e}$ & $\mathbf{N i}$ & Mo \\
\hline Electrode I & 1.27 & 18.72 & 1.86 & 70.65 & 5.05 & 2.45 \\
\hline Electrode II & 0.56 & 17.28 & 1.14 & 67.83 & 10.57 & 2.62 \\
\hline
\end{tabular}

Different concentrations of $\mathrm{H}_{3} \mathrm{PO}_{4}(0.05$ to $5 \mathrm{M})$ were used as the testing medium. Different concentrations of triazole derivatives namely; 3-amino-1, 2, 4-triazole (AT),4-amino-5-mercapto-1, 2, 4-triazole (AMT) in concentration range of $(0.25$ to $4 \%)$ were tested . Inorganic corrosion inhibitor; sodium opencircuit measurements were carried out in a conventional $150 \mathrm{ml}$ glass cell. The working electrode was mounted vertically and potential was measured with respect to an external saturated calomel electrode (SCE) interfaced to the test solution via a salt bridge. The working electrode was immersed in the test solution and the potential was recorded as a function of time till steady state potential values were established. The potential measurements were carried out at room temperature $\left(25 \pm 2^{\circ} \mathrm{C}\right)$, using electronic multimeter (Type Escord EDM2116). Potentiodynamic polarization measurements were performed using Autolab PG STAT 30. Electrochemical cell $(150 \mathrm{ml})$ with a standard three electrodes arrangement was used where the specimen used as the working electrode, platinum sheet auxiliary electrode and $\mathrm{Ag} / \mathrm{AgCl}$ reference electrode. Potentiodynamic curves were recorded using a scan rate of $0.001 \mathrm{~V} / \mathrm{s}$ between $0.6 \mathrm{~V}$ to $1.2 \mathrm{~V}$ w.r. to $\mathrm{E}_{\text {corr. }}$ All measurements were performed in a freshly prepared aerated solutions at room temperature $\left(25 \pm 2^{\circ} \mathrm{C}\right)$. The effect of addition

Egypt. J. Chem. 57, No.1 (2014) 
of inorganic corrosion inhibitor $\left(\mathrm{Na}_{3} \mathrm{PO}_{4}\right)$ and organic corrosion inhibitor (aminotriazole) to the $0.5 \mathrm{M}$ of $\mathrm{H}_{3} \mathrm{PO}_{4}$ was investigated.

\section{Results and Discussion}

Open-circuit potential measurements

Figures $1 \& 2$ represent the variation of the steady state potential of the two stainless steel electrodes type (I and II) with time in solutions of different concentrations of $\mathrm{H}_{3} \mathrm{PO}_{4}(0.05-5.0 \mathrm{M})$. The steady potentials of the two electrodes type (I and II) have a general tendency to shift towards nobler values with decreasing acid concentrations.

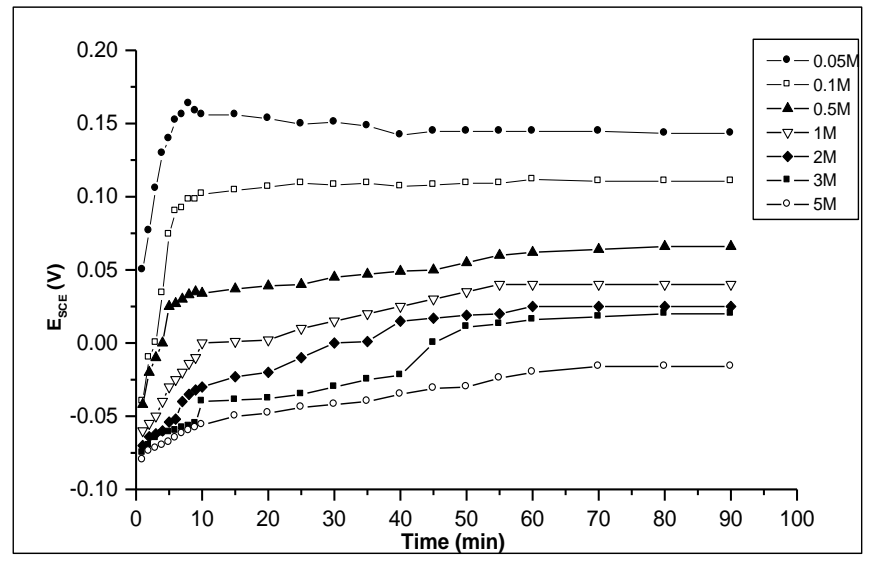

Fig.1. Variation of the steady state potential of the stainless steel electrode (I) with time in solutions of different concentrations of $\mathrm{H}_{3} \mathrm{PO}_{4}(0.05-5.0 \mathrm{M})$.

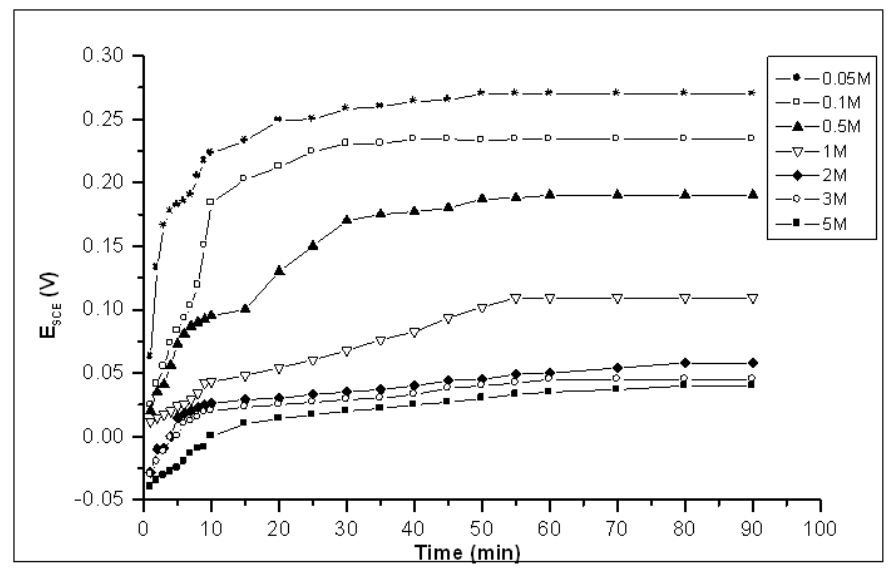

Fig.2. Variation of the steady state potential of the stainless steel electrode (II) with time in solutions of different concentrations of $\mathrm{H}_{3} \mathrm{PO}_{4}(0.05-5.0 \mathrm{M})$.

Egypt. J. Chem. 57, No.1 (2014) 
The potential-time curves of stainless steel electrodes type (I and II) in $\mathrm{H}_{3} \mathrm{PO}_{4}$ solutions show stable passivity at low acid concentrations. The transition to the active state being favored by increasing acid concentrations, then, the potential of both electrodes becomes more negative (active) as the concentration of $\mathrm{H}_{3} \mathrm{PO}_{4}$ is increased. For this application, anodic protection is required to maintain a passive state, which would otherwise undergo periodic breakdown ${ }^{(26-28)}$. In spite of the successful application of anodic protection, a consensus is yet to be attained on the nature of the passive state of stainless steels in this concentrated acid solution.

The immersion as well as the steady potential values for all concentrations in stainless steel electrodes seems to fall in $\mathrm{Fe}_{2} \mathrm{O}_{3}$ region of the pourbaix diagram ${ }^{(29)}$. The general shift to noble direction points toward oxidation of $\mathrm{Fe}_{3} \mathrm{O}_{4}$ to $\mathrm{Fe}_{2} \mathrm{O}_{3}$. The high positive shift indicates the high amount of $\mathrm{Fe}_{2} \mathrm{O}_{3}$ present in the layer.

$$
\begin{aligned}
& 4 \mathrm{Fe}_{3} \mathrm{O}_{4}+2 \mathrm{H}_{2} \mathrm{O}=6 \mathrm{Fe}_{2} \mathrm{O}_{3}+4 \mathrm{H}^{+}+4 \mathrm{e} \\
& 4 \mathrm{e}+\mathrm{O}_{2}+2 \mathrm{H}_{2} \mathrm{O}=4 \mathrm{OH}^{-} \\
& 4 \mathrm{Fe}_{3} \mathrm{O}_{4}+\mathrm{O}_{2}=6 \mathrm{Fe}_{2} \mathrm{O}_{3}
\end{aligned}
$$

The variation of steady-state potential $\left(\mathrm{E}_{\mathrm{st}}\right)$ of the two steel electrodes with the logarithm of the molar concentrations " $\mathrm{C}$ " of the acid solutions, is presented in Fig. 3. $\mathrm{E}_{\mathrm{st}}$ varies linearly with $\log \mathrm{C}$ according to equation:

$$
\mathrm{E}_{\mathrm{st}}=\mathrm{a}_{1}-\mathrm{b}_{1} \log \mathrm{C}
$$

where $a_{1}$ and $b_{1}$ are constants depending on the type of solution:" $a_{1}$ " represents the steady state potential $\mathrm{E}_{\mathrm{st}}$ in solution of $1.0 \mathrm{M}$ concentration, as obtained from the lines making the best fit with experimental result. Values of " $\mathrm{a}_{1}$ "are $0.07 \mathrm{~V}$ and $0.16 \mathrm{~V}$ for electrodes type I and II, respectively.

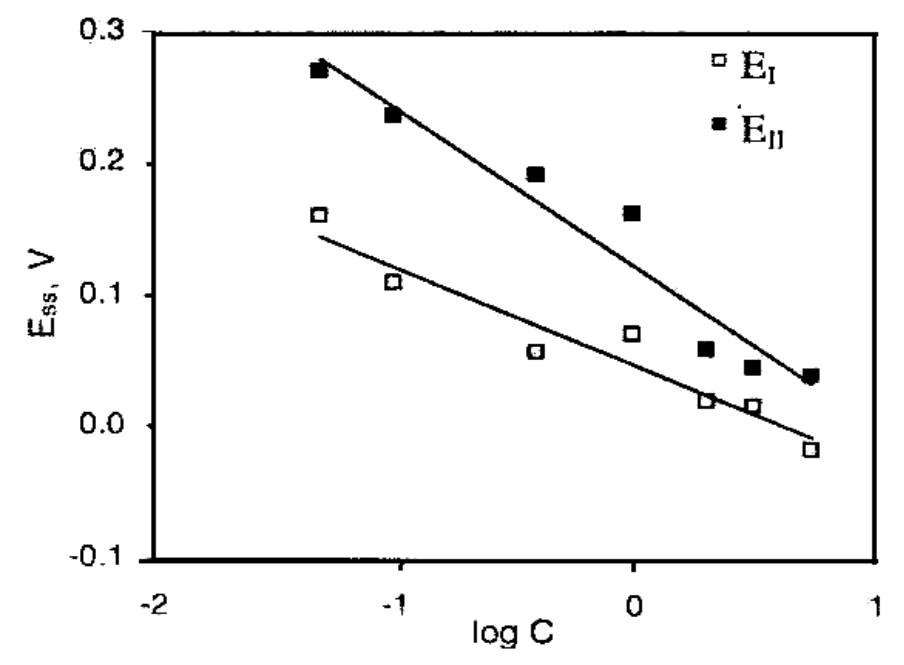

Fig. 3. $\mathrm{E}_{\mathrm{st}} / \log \mathrm{C}$ relations of electrodes $\mathrm{I} \& 2$ in different concentrations of $\mathrm{H}_{3} \mathrm{PO}_{4}$ solutions.

Egypt. J. Chem. 57, No.1 (2014) 
By presenting the data in the form of potential-log time curves, straight lines were obtained (Fig. 4\&5) satisfying the relation ${ }^{(30)}$.

$$
\mathrm{E}=\text { constant }+0.039(\delta) \log \mathrm{t}
$$

where: $\mathrm{t}$ is the time from the moment of immersion in solution and $\delta$ is the rate of oxide film thickening per unit decade of time. Potential of the two examined electrodes varies linearly with the logarithm of the immersion time until $\mathrm{E}_{\mathrm{st}}$ is attained. From the slopes of the two stainless steel electrodes examined. The values of $\delta$ thus obtained are isted in Table 2 .

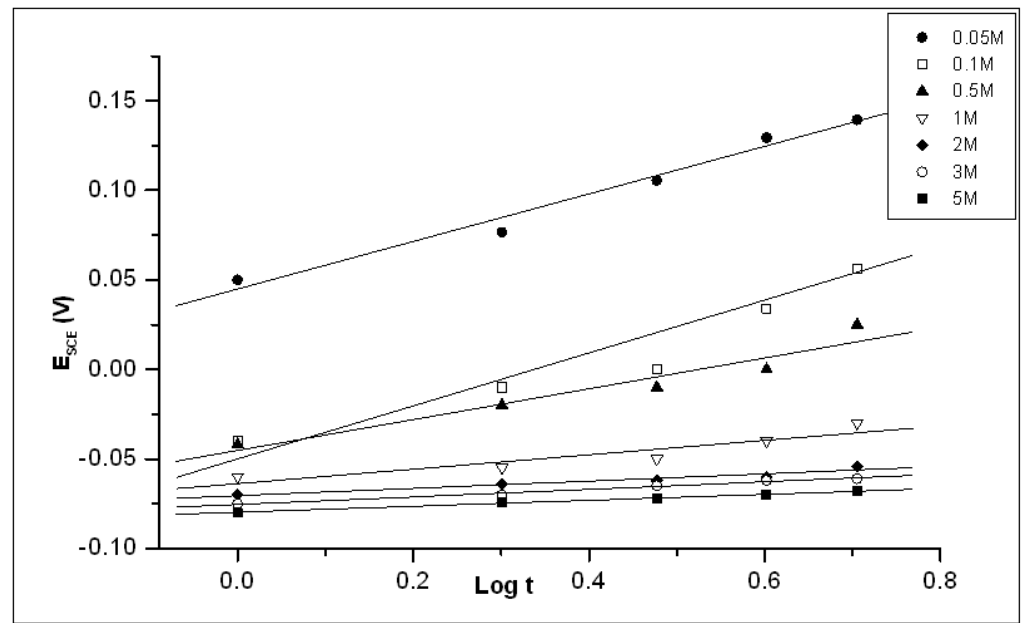

Fig.4. Potential / $/ \log \mathrm{t}$ relations of electrode $\mathrm{I}$ in different concentrations of $\mathrm{H}_{3} \mathrm{PO}_{4}$ solutions.

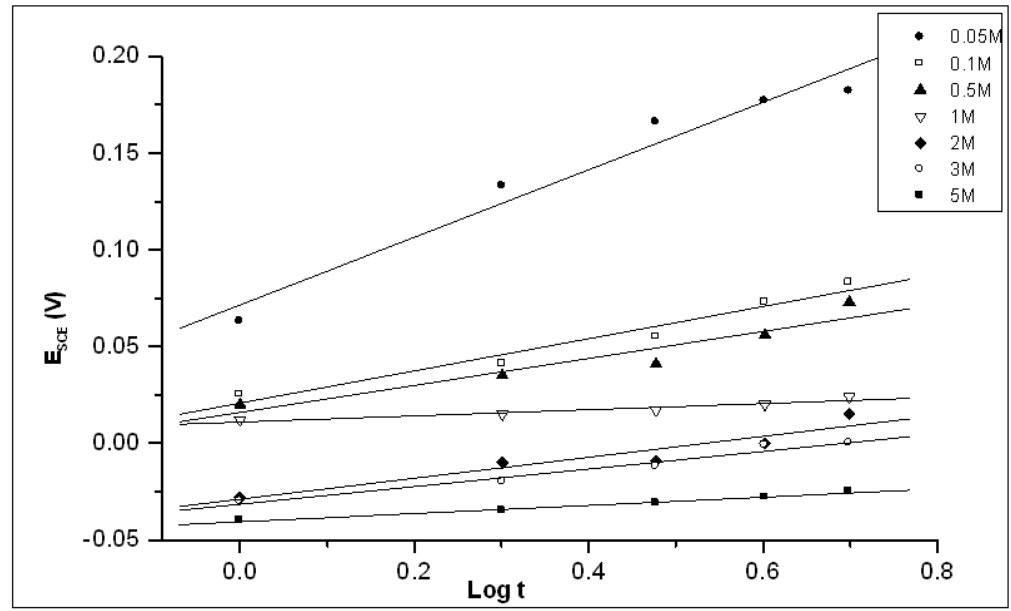

Fig. 5. Potential $/ \log \mathrm{t}$ relations of electrode $\mathrm{II}$ in different concentrations of $\mathrm{H}_{3} \mathrm{PO}_{4}$ solutions.

Egypt. J. Chem. 57, No.1 (2014) 
TABLE 2. Rates of film thickening $\delta$ (nm/time decade) of electrodes $I \&$ II in phpsohoric acid solutions.

\begin{tabular}{|c|c|c|}
\hline Concn / $\mathbf{M}$ & $\boldsymbol{\delta} \mathbf{E}_{\mathbf{I}}$ & $\boldsymbol{\delta E}_{\mathbf{I I}}$ \\
\hline 0.05 & 3.382 & 4.443 \\
\hline 0.1 & 3.338 & 2.118 \\
\hline 0.5 & 2.190 & 1.777 \\
\hline 1.0 & 1.024 & 0.405 \\
\hline 2.0 & 0.517 & 1.377 \\
\hline 3.0 & 0.536 & 1.157 \\
\hline 5.0 & 0.423 & 0.539 \\
\hline
\end{tabular}

\section{Potentiodynamic polarization measurements}

Potentiodynamic polarization measurements in phosphoric acid solutions

The potentiodynamic polarization curves of the two test electrodes type (I) and (II) in phosphoric acid solutions at $25^{\circ} \mathrm{C}$ are shown in Fig. 6\&7. The potentiodynamic polarization measurements were started at -450 up to 1200 $\mathrm{mVAg} / \mathrm{AgCl}$ against $\mathrm{E}_{\text {corr }}$. The electrochemical parameters of the test electrodes; corrosion potential, $\mathrm{E}_{\text {corr }}$, corrosion current density, $\mathrm{I}_{\text {corr }}$, corrosion rate, C.R., anodic Tafel slope, $\mathrm{B}_{\mathrm{a}}$ and cathodic Tafel slope, $\mathrm{B}_{\mathrm{c}}$, are recorded in Tables $3 \& 4$. For electrodes type (I) and (II), the corrosion potential value decreased and become more negative while corrosion current density value increased and became more anodic and the corrosion rate increased as the concentration of $\mathrm{H}_{3} \mathrm{PO}_{4}$ solutions increased from 0.05 to $5.0 \mathrm{M}$. Also, it is observed that anodic Tafel slope values for electrode type (I) decreases while the cathodic Tafel values is increasing as the concentration is increased. Cathodic current density is related to the hydrogen evolution.

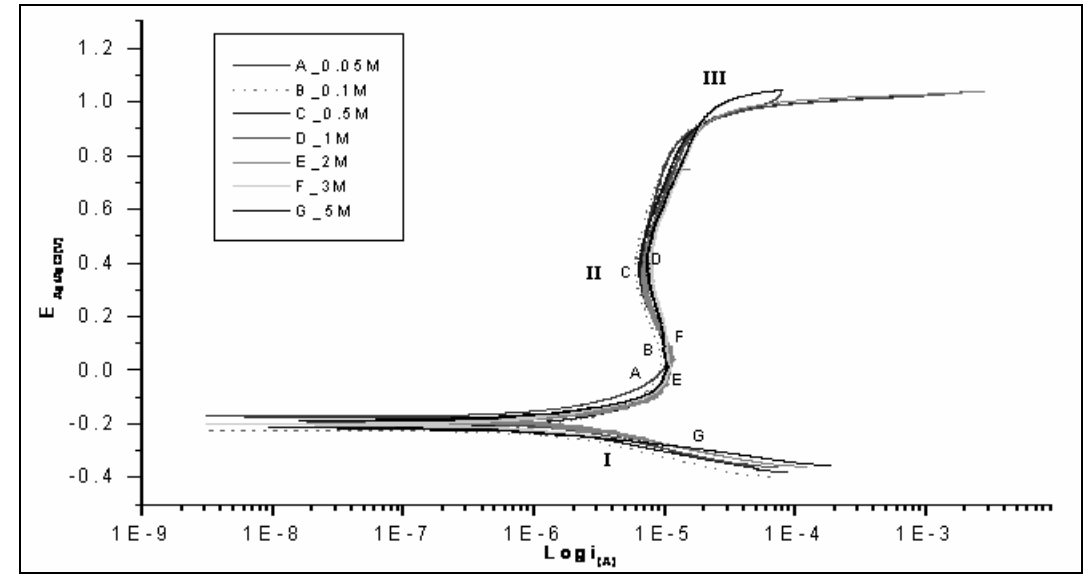

Fig. 6. Potentiodynamic polarization curves of stainless steel electrode (I) in solutions of different concentrations of $\mathrm{H}_{3} \mathrm{PO}_{4}(0.05-5.0 \mathrm{M})$.

Egypt. J. Chem. 57, No.1 (2014) 


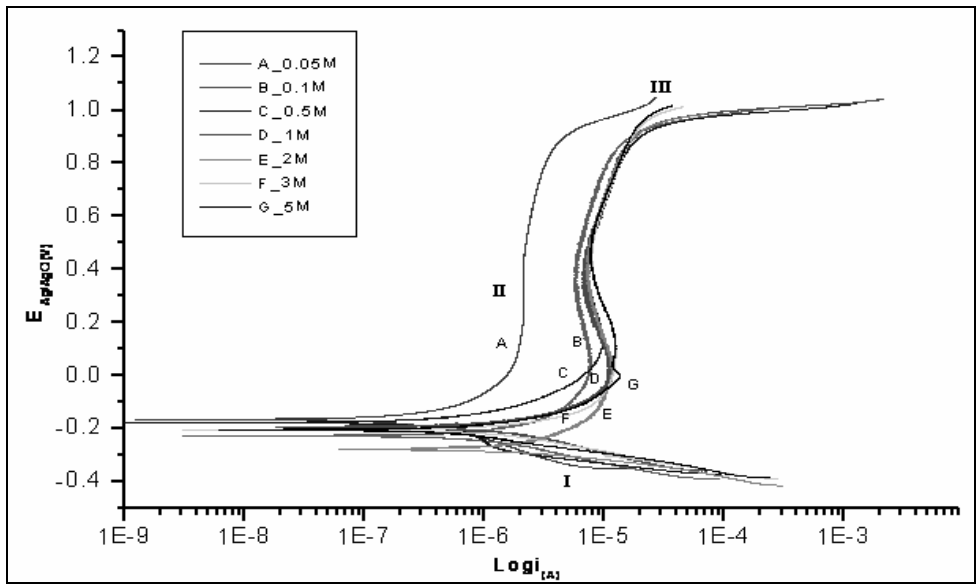

Fig.7. Potentiodynamic polarization curves of stainless steel electrode (II) in solutions of different concentrations of $\mathrm{H}_{3} \mathrm{PO}_{4}(0.05-5.0 \mathrm{M})$.

TABLE 3. Electrochemical parameters of electrode (I) in $\mathrm{H}_{3} \mathrm{PO}_{4}$ solutions.

\begin{tabular}{|c|c|c|c|c|c|}
\hline $\begin{array}{c}\text { Concn / } \\
\mathbf{M}\end{array}$ & $\mathbf{E}_{\text {corr }} / \mathbf{V}$ & \multicolumn{2}{|c|}{$\begin{array}{c}\text { Tafel Slopes } \\
\text { Ba }\end{array}$} & \multicolumn{1}{|c|}{$\begin{array}{c}\mathbf{I}_{\text {corr }} \\
\mathbf{A} / \mathbf{c m}^{2}\end{array}$} & $\begin{array}{c}\text { Corrosion } \\
\text { rate, mm/year }\end{array}$ \\
\hline 0.05 & -0.173 & 0.189 & 0.1116 & $6.142 \mathrm{E}-7$ & $1.119 \mathrm{E}-2$ \\
\hline 0.1 & -0.222 & 0.188 & 0.1115 & $8.977 \mathrm{E}-7$ & $1.613 \mathrm{E}-2$ \\
\hline 0.5 & -0.212 & 0.163 & 0.137 & $1.379 \mathrm{E}-6$ & $2.478 \mathrm{E}-2$ \\
\hline 1 & -.0191 & 0.16 & 0.140 & $2.211 \mathrm{E}-6$ & $4.221 \mathrm{E}-2$ \\
\hline 2 & -0.196 & 0.159 & 0.140 & $2.871 \mathrm{E}-6$ & $4.614 \mathrm{E}-2$ \\
\hline 3 & -0.224 & 0.15 & 1.394 & $1.341 \mathrm{E}-5$ & $8.122 \mathrm{E}-2$ \\
\hline $5 \mathrm{M}$ & -0.228 & 0.145 & 1.332 & $2.551 \mathrm{E}-5$ & $1.255 \mathrm{E}-1$ \\
\hline
\end{tabular}

TABLE 4. Electrochemical parameters of electrode (II) in $\mathrm{H}_{3} \mathrm{PO}_{4}$ solutions.

\begin{tabular}{|c|c|c|c|c|c|}
\hline Concn / M & \multirow{2}{*}{$\mathbf{E}_{\text {corr }} / \mathbf{V}$} & \multicolumn{2}{|c|}{$\begin{array}{c}\text { Tafel Slopes } \\
\text { Ba }\end{array}$} & $\begin{array}{c}\mathbf{I}_{\text {corr }} \\
\mathbf{B c}\end{array}$ & $\begin{array}{c}\text { Corrosion } \\
\mathbf{A} / \mathbf{c m}^{2}\end{array}$ \\
\hline $0.05 \mathrm{M}$ & -0.165 & 0.236 & 0.1554 & $2.686 \mathrm{E}-7$ & $4.825 \mathrm{E}-3$ \\
\hline $0.1 \mathrm{M}$ & -0.227 & 0.206 & 0.154 & $4.315 \mathrm{E}-7$ & $5.263 \mathrm{E}-3$ \\
\hline $0.5 \mathrm{M}$ & -0.176 & 0.1455 & 0.10223 & $9.797 \mathrm{E}-7$ & $1.76 \mathrm{E}-2$ \\
\hline $1 \mathrm{M}$ & -0.189 & 0.1321 & 0.1441 & $9.947 \mathrm{E}-7$ & $1.816 \mathrm{E}-2$ \\
\hline $2 \mathrm{M}$ & -0.279 & 0.1088 & 0.1221 & $.8741 \mathrm{E}-6$ & $1.814 \mathrm{E}-2$ \\
\hline $3 \mathrm{M}$ & -0.284 & 0.0906 & 0.1072 & $1.062 \mathrm{E}-6$ & $1.907 \mathrm{E}-2$ \\
\hline $5 \mathrm{M}$ & -0.285 & 0.0511 & 0.0944 & $2.224 \mathrm{E}-6$ & $0.947 \mathrm{E}-1$ \\
\hline
\end{tabular}


Anodic polarization curves indicate three regions. The first region represents active dissolution region was observed from -450 to -100 and to -175 $\mathrm{mVAg} / \mathrm{AgCl}$ where the potential-current relations were linear with a well defined Tafel slope. The second region a current peak signifying the transition from active dissolution to passive state on electrode surface, from -50 to 800 , zero to $850 \mathrm{mVAg} / \mathrm{AgCl}$. Third region represents a transpassive region at 850 to 1000 , 950 to $1100 \mathrm{mVAg} / \mathrm{AgCl}$, for $\mathrm{H}_{3} \mathrm{PO}_{4}$ acid solutions. Oxygen started to evolve and the current density increased sharply with further increase in potential. Increasing the acid concentration shifts the critical current density, active-passive transition potential and passive-transpassive transition potential region toward the active direction.

The composition of the passive film of stainless steel electrodes formed in (0.05-5.0M) $\mathrm{H}_{3} \mathrm{PO}_{4}$ solution essentially composes from ferric phosphate, chromium phosphate and $\mathrm{Fe}_{2} \mathrm{O}_{3}{ }^{(31)}$. The most interesting feature of film composition of stainless steel containing Mo is the existence of low amount of oxidized iron and phosphate together with remarkable enrichment in hexavalent Mo and trivalent chromium. This suggests that the passive effect of chromium is reinforced probably by the formation of silico-molybdic compounds stable at the acid concentrations studied.

Finally, the passive film of the Mo containing stainless steels shows an enrichment in $\mathrm{Mo}(\mathrm{VI}), \mathrm{Si}(\mathrm{IV})$ and $\mathrm{Cr}(\mathrm{III})$ and a small amount of phosphate and oxidized iron ${ }^{(32)}$. It is found that the improved corrosion behavior is directly correlated to its enrichment in silicon and molybdenum, and with depletion in iron in the surface film. This suggests that the protective properties of the passive film on Mo-stainless steel are correlated to the formation of silico-molybdichydrate compounds. In the active range, Mo dissolves in an oxidized state $\mathrm{Mo}(\mathrm{III})$, which are oxidized into $\mathrm{MoO}_{4}{ }^{2-}$ or $\mathrm{HMoO}_{4}{ }^{-}$which are stable in the concentrations of $\mathrm{H}_{3} \mathrm{PO}_{4}$ acid examined. They are adsorbed in the alloy surface and interact with various species, giving both mixed phosphate of $\mathrm{Fe}, \mathrm{Cr}$, Mo and simple phosphate $\left[\mathrm{H}_{3}\left(\mathrm{PMo}_{12} \mathrm{O}_{40}\right)\right]^{(33)}$. Moreover, there is the probable appearance of silico-molybdic-hydrate complex that provides enough protection. The principle of these should be $\mathrm{H}_{4}\left(12 \mathrm{MoO}_{3}, \mathrm{SiO}_{2}\right) \cdot \mathrm{nH}_{2} \mathrm{O}$ particularly stable in acidic solutions ${ }^{(34)}$.

Effect of addition of $\mathrm{PO}_{4}{ }^{3-}$ inorganic anions on the electrochemical behavior of stainless steel electrodes in $0.5 \mathrm{M} \mathrm{H}_{3} \mathrm{PO}_{4}$

The effect of addition of sodium orthophosphate on the electrochemical behavior of stainless steel electrodes type (I) and (II) in $0.5 \mathrm{M}$ phosphoric acid solution were examined using potentiodynamic measurements at scan rate of 1 $\mathrm{mV} / \mathrm{s}$. Anodic and cathodic curves were generated potentiodynamically (Fig. 8 \&9), to investigate the effect of tri-basic sodium phosphate, $\mathrm{Na}_{3} \mathrm{PO}_{4}$, dosage (4-57\%) on the corrosion behavior of electrodes in $0.5 \mathrm{M}$ of phosphoric acid, $\mathrm{H}_{3} \mathrm{PO}_{4}$, solution. The electrochemical parameters in absence and presence of different concentrations of the additives are given in Tables $5 \& 6$.

Egypt. J. Chem. 57, No.1 (2014) 
It was found that, upon increasing inhibitor concentration in the used acid solution, the corrosion current $\left(\mathrm{I}_{\text {corr }}\right)$ decreases and the corrosion rate decreases; furthermore the $\mathrm{pH}$ of the solution changed in the range from 1.7 to 10.7. Therefore, the protective property of additive depends on the $\mathrm{pH}$ value of the solution. The slopes of the anodic and cathodic Tafel lines $\left(\mathrm{B}_{\mathrm{a}}\right.$ and $\left.\mathrm{B}_{\mathrm{c}}\right)$ almost changed upon increasing the concentration of phosphate. This indicates that the used inhibitor has an effect on the mechanism of the dissolution of the used steel electrodes.

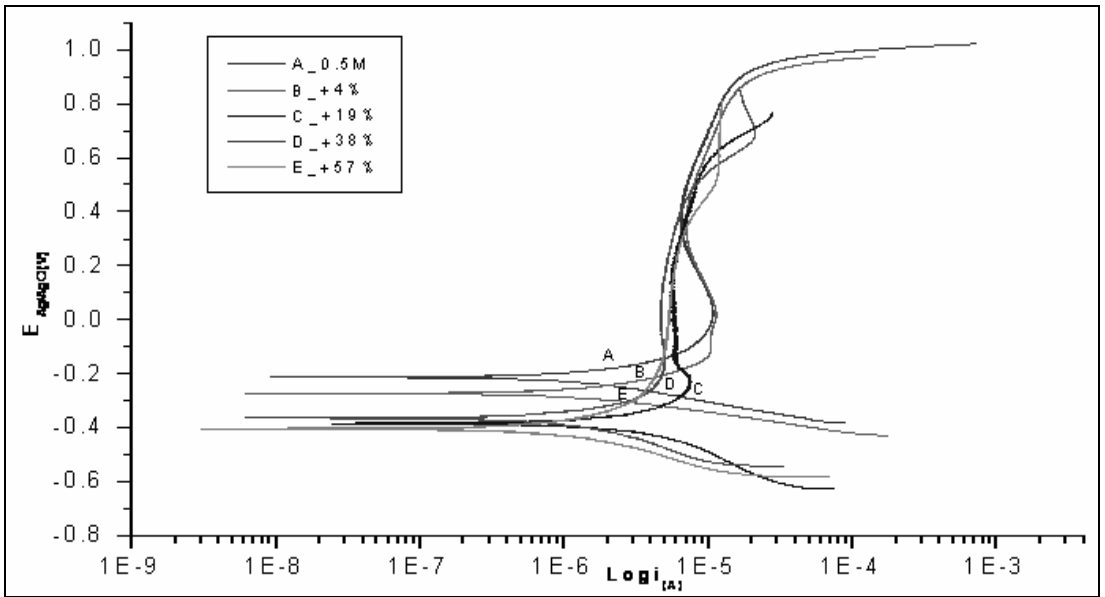

Fig. 8. Potentiodynamic polarization curves of stainless steel electrode (I) in $0.5 \mathrm{M}$ $\mathrm{H}_{3} \mathrm{PO}_{4}$ solution in the presence of $\mathrm{Na}_{3} \mathrm{PO}_{4}$ as inorganic corrosion inhibitor.

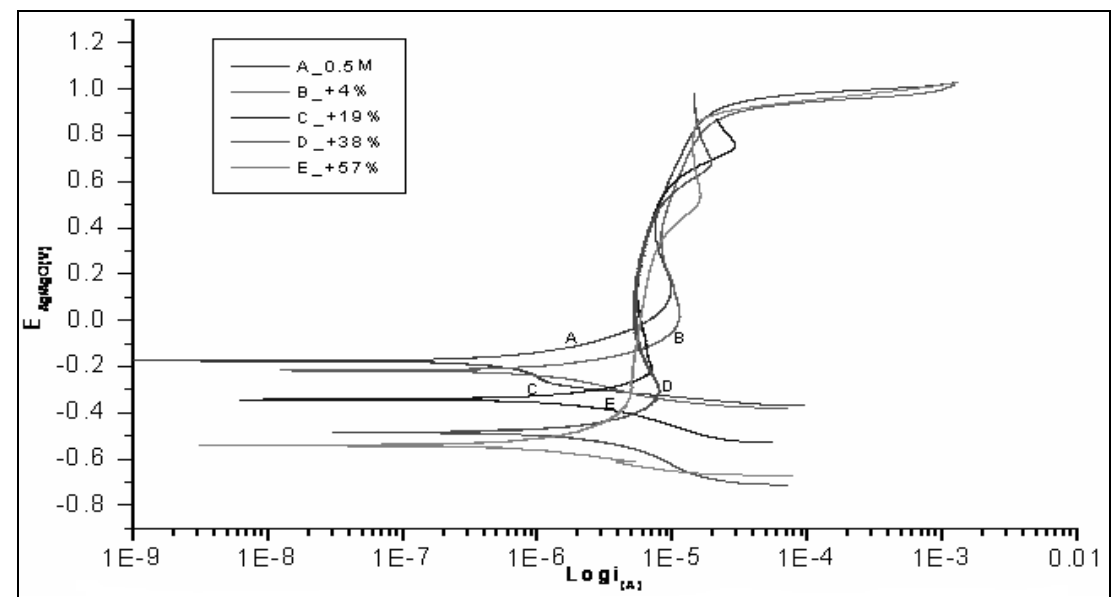

Fig.9. Potentiodynamic polarization curves of stainless steel electrode (II) in $0.5 \mathrm{M}$ $\mathrm{H}_{3} \mathrm{PO}_{4}$ solution in the presence of $\mathrm{Na}_{3} \mathrm{PO}_{4}$ as inorganic corrosion inhibitor.

Egypt. J. Chem. 57, No.1 (2014) 
TABLE 5. The corrosion parameters together and inhibition efficiency, (I.E\%) of electrode (I) in $0.5 \mathrm{M} \mathrm{H}_{3} \mathrm{PO}_{4}$ containing 4-57\% sodium orthophosphate.

\begin{tabular}{|c|c|c|c|c|c|c|}
\hline \multirow{2}{*}{ \% Na $\mathbf{N a}_{3} \mathbf{P O}_{\mathbf{4}}$} & \multirow{2}{*}{$\mathbf{E}_{\text {corr }} / \mathbf{V}$} & \multicolumn{2}{|c|}{ Tafel Slopes } & \multirow{2}{*}{$\begin{array}{c}\mathbf{I}_{\text {corr }} \\
\mathbf{A} / \mathbf{c m}^{2}\end{array}$} & $\begin{array}{c}\text { Corrosion rate } \\
\mathbf{m m} / \mathbf{y e a r}\end{array}$ & $\begin{array}{c}\text { Inhibition } \\
\text { efficiency } \\
\text { (I.E\%) }\end{array}$ \\
\cline { 3 - 4 } & & $\mathbf{B a}$ & $\mathbf{B c}$ & & & -- \\
\hline 0.0 & -0.212 & 0.163 & 0.137 & $1.38 \mathrm{E}-6$ & $2.478 \mathrm{E}-2$ & 12.18 \\
\hline 4 & -0.251 & 0.151 & 0.136 & $1.21 \mathrm{E}-6$ & $1.047 \mathrm{E}-2$ & 40.97 \\
\hline 19 & -0.383 & 0.125 & 0.135 & $8.14 \mathrm{E}-7$ & $9.911 \mathrm{E}-3$ & 63.17 \\
\hline 38 & -0.387 & 0.120 & 0.135 & $5.08 \mathrm{E}-7$ & $9.023 \mathrm{E}-3$ & 84.57 \\
\hline 57 & -0.401 & 0.055 & 0.107 & $2.13 \mathrm{E}-7$ & $7.547 \mathrm{E}-3$ & \\
\hline
\end{tabular}

TABLE 6. The corrosion parameters together and inhibition efficiency, (I.E\%) of electrode (I) in $0.5 \mathrm{M} \mathrm{H}_{3} \mathrm{PO}_{4}$ containing 4-57\% sodium orthophosphate.

\begin{tabular}{|c|c|c|c|c|c|c|}
\hline \multirow{2}{*}{$\% \mathbf{N a}_{3} \mathbf{P O}_{\mathbf{4}}$} & \multirow{2}{*}{\begin{tabular}{|}
$\mathbf{E}_{\text {corr }}$ \\
$\mathbf{V}$
\end{tabular}} & \multicolumn{2}{|c|}{ Tafel Slopes } & \multirow{2}{*}{$\begin{array}{c}\mathbf{I}_{\text {corr }} \\
\mathbf{A} / \mathbf{c m}^{2}\end{array}$} & $\begin{array}{c}\text { Corrosion } \\
\text { rate } \\
\mathbf{m m} / \mathbf{y e a r}\end{array}$ & $\begin{array}{c}\text { Inhibition } \\
\text { efficiency (\%) }\end{array}$ \\
\hline 0.0 & -0.176 & 0.146 & 0.102 & $9.797 \mathrm{E}-7$ & $1.760 \mathrm{E}-2$ & -- \\
\hline 4 & -0.227 & 0.075 & 0.103 & $4.061 \mathrm{E}-7$ & $7.295 \mathrm{E}-3$ & 58.55 \\
\hline 19 & -0.342 & 0.065 & 0.100 & $1.152 \mathrm{E}-7$ & $3.121 \mathrm{E}-3$ & 88.24 \\
\hline 38 & -0.478 & 0.061 & 0.099 & $9.922 \mathrm{E}-8$ & $1.782 \mathrm{E}-3$ & 89.87 \\
\hline 57 & -0.538 & 0.055 & 0.074 & $5.312 \mathrm{E}-8$ & $5.121 \mathrm{E}-4$ & 94.58 \\
\hline
\end{tabular}

The behavior of stainless steel electrodes type (I) and (II) in aerated $\mathrm{HPO}_{4}{ }^{2-}$ ion solutions exhibited an active-passive behavior. The polarization measurements were performed from the cathodic potential through the active and passive regions. At the beginning of the curve at a potential of $-600 \mathrm{mVAg} / \mathrm{AgCl}$, the electrode is activated. The positive change in potential causes an increase in dissolution rate for the stainless steel electrodes. Following this, the anodic current increases slightly with a rise in potential till value of approximately 900 $\mathrm{mVAg} / \mathrm{AgCl}$ at which the electrode becomes passive, forming a protective film on the electrode surface.

The protective film formed on the stainless steel electrodes type (I) and (II) in $\mathrm{PO}_{4}{ }^{3-}$ solutions consists of $\delta-\mathrm{Fe}_{2} \mathrm{O}_{3}$ with $\mathrm{FePO}_{4} \cdot \mathrm{H}_{2} \mathrm{O}$ particles imbedded in it ${ }^{(35,36)}$. The high corrosion resistance of steel in phosphates solutions is undoubtedly due to the formation of sparingly soluble salts and it can serve as an illustration of the specific effect of the anion ${ }^{(35)}$.

The experimental data in phosphate medium of $\mathrm{pH}$ values from 1.7 to 10.7 , allowed proposing a dissolution-precipitation mechanism type in order to interpret the presence of the first anodic peak and its evolution in relation with the experimental

Egypt. J. Chem. 57, No.1 (2014) 
parameters studied. Phosphate ions are consumed, through a control by diffusion towards the interface, leading to a decrease of electrode active surface which is caused by precipitation of the oxidized iron species. The second peak is due to oxide formation rather than precipitate ${ }^{(37,38)}$. It is also clear that the inhibition effect of phosphate is due to the partial passivation of the electrode exerts on indirect effect of the cathodic reaction, increasing its rate and will retard the anodic reaction. It is also found that electrode type (II) is more affected than electrode type (I), the high efficiency is $94.6 \%$ in $57 \%$ concentration for electrode type (II) and is $84.6 \%$ in the same concentration of solution for electrode type (I).

Effect of addition of 3-amino 1, 2, 4-triazole (AT) on the electrochemical behavior of stainless steel electrodes in various acid solutions

The role of some organic compounds, such as 3-amino 1,2,4 triazole (AT) solution in the retardation of corrosion of stainless steel in $0.5 \mathrm{M} \mathrm{H}_{3} \mathrm{PO}_{4}$ acid was studied using potentiodynamic technique.

Figures $10 \& 11$ show the potentiodynamic polarization curves of stainless steel (I) and (II) in aerated solutions of $0.5 \mathrm{M} \mathrm{H}_{3} \mathrm{PO}_{4}$ in absence and presence of varying concentrations of AT $(1-4 \%)$ at scanning rate of $0.001 \mathrm{~V} / \mathrm{sec}$. The electrochemical parameters derived from these curves are listed in Tables $7 \& 8$. The results obtained indicate that, in all cases, upon increasing the AT concentration, the values of $\mathrm{E}_{\text {corr }}, \mathrm{I}_{\text {corr }}$, Tafel slopes, $\left(\mathrm{B}_{\mathrm{a}}, \mathrm{B}_{\mathrm{c}}\right)$ and corrosion rate decrease. The corrosion inhibition behavior of AT in acid solution may be due to the formation of Fe-AT complex, which can impede the aggressive anions to reach to the base stainless steel surface through the pits. The inhibition efficiency depends on the concentration of the inhibitor. It seems that a formation of Fe-AT complex, where it can form stable passive layer on the stainless steel surface, leads to the decreasing of corrosion rate ${ }^{(39-41)}$. The inhibition efficiency increases by increasing the inhibitor concentration and reaching a maximum at $4 \%$ AT.

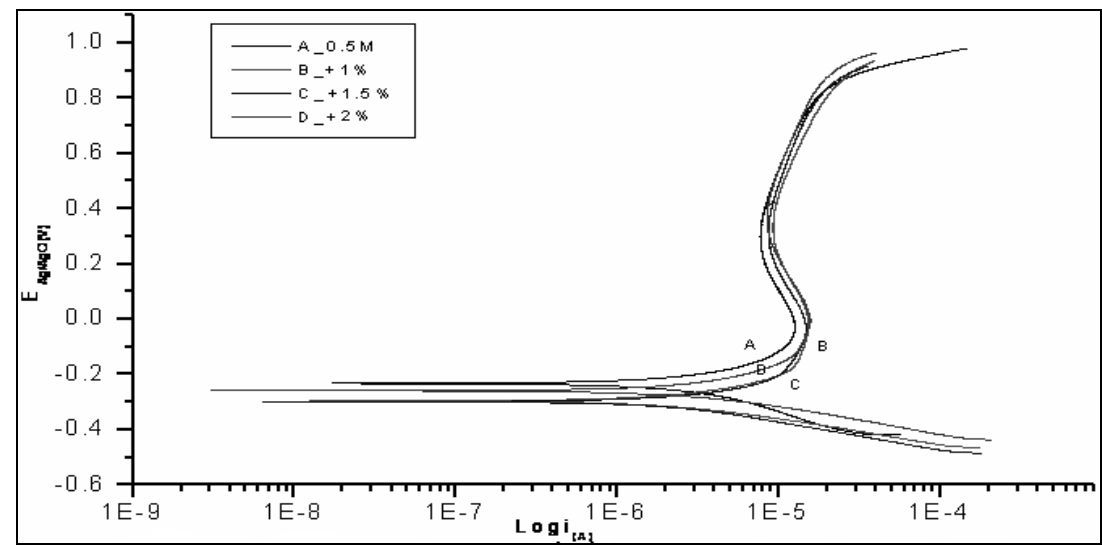

Fig.10. Potentiodynamic polarization curves of stainless steel electrode (I) in $0.5 \mathrm{M}$ $\mathrm{H}_{3} \mathrm{PO}_{4}$ solution in the presence of aminotriazole as organic corrosion inhibitor.

Egypt. J. Chem. 57, No.1 (2014) 


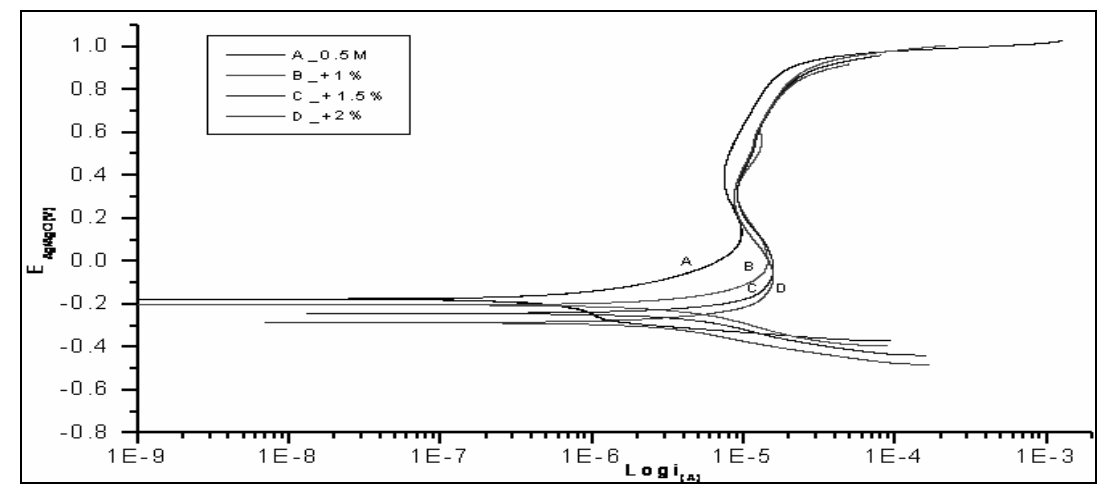

Fig.11. Potentiodynamic polarization curves of stainless steel electrode (II) in $0.5 \mathrm{M}$ $\mathrm{H}_{3} \mathrm{PO}_{4}$ solution in the presence of aminotriazole as organic corrosion inhibitor.

TABLE 7. Corrosion parameters and inhibition efficiency, (I.E\%) of electrode (I) in $0.5 \mathrm{M} \mathrm{H}_{3} \mathrm{PO}_{4}$ in the presence of 1-2\% AT inhibitor.

\begin{tabular}{|c|c|c|c|c|c|c|}
\hline \multirow{2}{*}{ \% AT } & \multirow{2}{*}{$\mathbf{E}_{\text {corr }} / \mathbf{V}$} & \multicolumn{2}{|c|}{ Tafel Slopes } & \multirow{2}{*}{$\begin{array}{c}\mathbf{I}_{\text {corr }} \\
\text { A/cm }\end{array}$} & $\begin{array}{c}\text { Corrosion } \\
\text { rate } \\
\text { mm/year }\end{array}$ & $\begin{array}{c}\text { Inhibition } \\
\text { efficiency } \\
\text { (I.E\%) }\end{array}$ \\
\hline 0.0 & -0.212 & 0.1625 & 0.137 & $1.379 \mathrm{E}-6$ & $2.478 \mathrm{E}-2$ & -- \\
\hline 1 & -0.259 & 0.1383 & 0.092 & $1.344 \mathrm{E}-6$ & $2.415 \mathrm{E}-2$ & 2.54 \\
\hline 1.5 & -0.298 & 0.0865 & 0.097 & $1.098 \mathrm{E}-6$ & $1.972 \mathrm{E}-2$ & 20.38 \\
\hline 2 & -0.299 & 0.057 & 0.096 & $3.156 \mathrm{E}-7$ & $5.669 \mathrm{E}-3$ & 77.11 \\
\hline
\end{tabular}

TABLE 8. Corrosion parameters and inhibition efficiency, (I.E\%) of electrode (II) in $0.5 \mathrm{M} \mathrm{H}_{3} \mathrm{PO}_{4}$ in the presence of $1-2 \%$ AT inhibitor .

\begin{tabular}{|c|c|c|c|c|c|c|}
\hline AT \% & \multirow{2}{*}{\begin{tabular}{|}
$\mathbf{E}_{\text {corr }}$ \\
$\mathbf{V}$
\end{tabular}} & \multicolumn{2}{|c|}{$\begin{array}{c}\text { Tafel Slopes } \\
\text { Ba }\end{array}$} & \multicolumn{1}{|c|}{$\begin{array}{c}\mathbf{I}_{\text {corr }} \\
\mathbf{A} / \mathbf{c m}^{2}\end{array}$} & $\begin{array}{c}\text { Corrosion } \\
\text { rate } \\
\text { mm/year }\end{array}$ & $\begin{array}{c}\text { Inhibition } \\
\text { efficiency } \\
\text { (I.E\%) }\end{array}$ \\
\hline 0.0 & -0.176 & 0.1455 & 0.1022 & $9.797 \mathrm{E}-7$ & $1.76 \mathrm{E}-2$ & -- \\
\hline 1.0 & -0.203 & 0.101 & 0.1007 & $9.744 \mathrm{E}-7$ & $1.446 \mathrm{E}-2$ & 0.540982 \\
\hline 1.5 & -0.242 & 0.0828 & 0.0451 & $8.051 \mathrm{E}-7$ & $1.11 \mathrm{E}-2$ & 17.82178 \\
\hline 2.0 & -0.286 & 0.0551 & 0.0926 & $6.179 \mathrm{E}-7$ & $1.75 \mathrm{E}-3$ & 36.92967 \\
\hline
\end{tabular}

This variation of inhibition effect of AT in different acid solution between stainless steel electrodes type (I) and (II) may be due to the change in the composition of the two electrodes especially in the nickel percentage, which increases probability of dissolution of the complex layer formed at the electrode surface.

Egypt. J. Chem. 57, No.1 (2014) 


\section{Conclusions}

- The composition of the passive film of stainless steel electrodes formed in $\mathrm{H}_{3} \mathrm{PO}_{4}$ solution essentially composes from ferric phosphate, chromium phosphate and $\mathrm{Fe}_{2} \mathrm{O}_{3}$. Mo enhances corrosion resistance of stainless steels which is directly correlated to its enrichment in silicon and molybdenum, and with depletion in iron in the surface film.

- The high corrosion resistance of stainless steel in phosphates solutions is due to the formation of sparingly soluble salts, and it can serve as an illustration of the specific effect of the anion.

- AT compound has proven to be efficient inhibitor for general and pitting corrosion of stainless steel in acid solutions. The inhibition efficiency increases by increasing the inhibitor concentration. The inhibitive property may be argued to the formation of very low soluble layer and a compact Fe-AT complex film on the electrode surface.

\section{References}

1. Agrawal, B. K., Introduction to Engineering Materials. Tata MacGraw Hill Edition, 154 (4) 63 (1998)

2. William, F. Smith, Structure and Properties of Engineering Alloys, Mcgraw-Hill Inc, $2^{\text {nd }}$ edition, Chapter 7(1993).

3. Hashimoto, K., Asami, K., Kawashima, A., Habazaki, H. and Akiyama, E., The role of corrosion-resistant alloying elements in passivity. Corros. Sci. 49, 42 (2007).

4. Merello, R.A., Botanab, F.J., Botella, J.A., Martes, M.V.A., Marcos, M.B. and Acerinox, S.A., Influence of chemical composition on the pitting corrosion resistance of non-standard low-Ni high-Mn-N duplex stainless steels. Corros. Sci. 45, 909(2003)

5. Martins, M. and Casteletti, L.C., Heat treatment temperature influence on ASTM A890 GR 6A super duplex stainless steel microstructure. Materials Characterization, 55 (3), 225(2005).

6. Back, G. and Singh, P. M., The characterization of passive films on chromium electrodes by XPS. Corros. Sci. 46, 2159(2004).

7. Shreir, L.L. and Burstein, Jarman, G.T., Corrosion, Metal / Environment Reaction, Butterworth-Heinemann, UK, (1976).

8. Abellah, G., Hajji, M.A., El Miloudi, J. and Ben Bachir, A., Study of corrosion-erosion behaviour of stainless alloys in industrial phosphoric acid medium. App. Surf. Sci. 253 (5), 2362(2006).

9. Wang, H., Jiang, Y., Qu, J., Cao, Z., Liu, S. and Guo, X., Adenine as an effective corrosion inhibitor for stainless steel in chloride solution. International Journal of Iron and Steel Research, 8, 9201 - 9221(2013). 
10. Quartarone, G., Bonaldo, L. and Tortato, C., Inhibitive action of indole-5-carboxylic acid towards corrosion of mild steel in deaerated $0.5 \mathrm{M}$ sulfuric acid solutions. Appl. Surf. Sci. 252, 8251(2006).

11. Tizpar, A. and Ghasemi, Z., Corrosion inhibition of iron in $20 \%$ hydrochloric acid by 1,4/1,6-bis( $\alpha$-octylpyridinium) butane/hexane. Dibromide Corro. Sci. 252, 8630(2006).

12. John, D., Blom, A., Bailey, S., Nelson, A., Schulz, J., De Marco, R. and Kinsella, B., Investigation of reference samples for residual strain measurements in a welded specimen by neutron and synchrotron X-ray diffraction. Physica B, 924, 385-386 (2006).

13. Deyab, M.A., Effect of cationic surfactant and inorganic anions on the electrochemical behavior of carbon steel in formation water. Corro. Sci. 49, 2315(2007) .

14. Qiu, L.G., Wang, Y.M. and Jiang, X., Synergistic effect between cationic gemini surfactant and chloride ion for the corrosion inhibition of steel in sulphuric acid. Corros. Sci. 50, 576(2008).

15. Bentiss, F. ,Traisnee, M. and Lagreneem, M., The substituted 1,3,4-oxadiazoles: a new class of corrosion inhibitors of mild steel in acidic media. Corros. Sci. 42,127(2000).

16. Chetouani, A. , Aouniti, A., Hammouti, B., Benchat, Benhadda, T. and Kertit, S., Corrosion inhibitors for iron in hydrochloride acid solution by newly synthesised pyridazine derivatives. Corros. Sci. 45, 1675(2003).

17. Lagrene'e, M., Memaru, B., Chaibi, N., Traisnel, M., Vezin, H. and Bentiss, F., Corros. Sci. 43, 951(2001).

18. Abdel-Rehim, S.S. Refaey, S.A.M., Taha, F., Saleh, M.B. and Ahmed, R.A., Corrosion inhibition of mild steel in acidic medium using 2-amino thiophenoland 2cyanomethyl benzothiazole. J. Appl. Electrochem. 31, 429(2001).

19. Bentiss, F., Traisnel, M., Chaibi, N., Mernari, B., Vezin, H., Lagrenée, M., 2,5-Bis(nmethoxyphenyl)-1,3,4-oxadiazoles used as corrosion inhibitors in acidic media: correlation between inhibition efficiency and chemical structure. Corros. Sci. 44, 2271(2002).

20. Benkaddour, M., Oudda, H., Hammouti, B. and Ramdani, A. The inhibitive effect of bipyrazolic derivatives on the corrosion of steel in hydrochloric acid solution. Appl. Surf. Sci. 241, 326(2005).

21. Bouklah,M., Attayibat, A., Kertit, S., Ramdani, A. and Hammouti, B., A pyrazine derivative as corrosion inhibitor for steel in sulphuric acid solution. App. Surf. Sci. 242, 399 (2005).

22. Qurraishi, M.A. and Sharma, H.K., 4-Amino-3-butyl-5-mercapto-1, 2, 4-triazole: a new corrosion inhibitor for mild steel in sulphuric acid. Mater. Chem. Phys. 8 ,8 (2002).

23. Chebabe, D., Chikh, Z.A., Hajjaji, N., Sehiri, A.A. and Zucchi, F., Corrosion inhibition of Armco iron in $1 \mathrm{M} \mathrm{HCl}$ solution by alkyltriazoles. Corros. Sci. 45,309(2003).

Egypt. J. Chem. 57, No.1 (2014) 
24. Bentiss, F., Traise, M., Gengembre, L. and Lagren'ee, M., Inhibition of acidic corrosion of mild steel by 3,5-diphenyl-4H-1,2,4-triazole. App. Surf. Sci. 161, 194 (2002).

25. Bentiss, F., lagrenee, M., Traisnel, M. and Hornez, J.C., Corros. Sci. 41, 789(1999).

26. Chang, Y.S., Active passive corrosion behavior, Ph.D. Dissertation, Cambidge University, Cambridge (1984).

27. Wang, H. and Turner, J.A., A review of metallic bipolar plates for proton exchange membrane fuel cells: materials and fabrication methods. Journal of Power Sources, 180 (2) 803(2008).

28. Escrivà-Cerdán, C., Blasco-Tamarit, E., García-García, D.M., García-Antón, J. and Guenbour, A., Effect of potential formation on the electrochemical behaviour of a highly alloyed austenitic stainless steel in contaminated phosphoric acid at different temperatures. Electrochimica Acta, 80, 248(2012).

29. Pourbaix, M., Atlas of Electrochemical Equilibrium in Aqueous Solutions, Pergamon Press. Oxford, pp.308-3110 (1966).

30. Abd El Kader, J.M. and Shams El Din, A.M., Br. Corros. J. 14 (1), 50(1979).

31. lewis, G., Fox, P.G. and Bboden, P.J., Electrochemical aspects of stress corrosion crack growth in austenitic stainless steel. Corros. Sci. 20, 331(1980).

32. Rhodin, T.N., The relation of thin films to corrosion. Corros. 12, 465(1956).

33. Lee J.P., Elevated temperature potential-pH diagrams for the $\mathrm{Cr}-\mathrm{H}_{2} \mathrm{O}$, Ti- $\mathrm{H}_{2} \mathrm{O}, \mathrm{Mo}-\mathrm{H}_{2} \mathrm{O}$ and $\mathrm{Pt}-\mathrm{H}_{2} \mathrm{O}$ systems. Corrosion, 37, 467(1981).

34. Guenbour, A., Fatichcu, J. and Ben Bachir, A., On the mechanism for improved passivation by addition of molybdenum to austenitic Stainless steels in O-phosphoric acid. Corros. 44 (4), 214(1988).

35. Evans, U.R., An Introduction to Metallic Corrosion, Edward Arnold, London (1960).

36. Rozefeld, I.L., Corrosion Inhibitors, McGraw-Hill. Inc., 175 (1981).

37. Conway, B.E. and Kannangra, D.C. W., Zinc oxidation and redeposition processes in aqueous alkali and carbonate solutions: II . Distinction between dissolution and oxide film formation processes. J. Electrochem. Soc. 134, 906(1987).

38. Benzakour, J. and Derja, A., Electrochemical passivation of iron in phosphate medium. Electrochim. Acta, 38, 254(1993).

39. Mert, B. D., Mert, M. E., Kardaş,V. and Yazcı, B., Experimental and theoretical investigation of 3-amino-1, 2, 4-triazole-5-thiol as a corrosion inhibitor for carbon steel in HCl medium. Corros. Sci. 53 (12), 4265(2011). 
40. Markhali, B.P., Naderi, R., Mahdavian, M., Sayebani, M. and Arman, S.Y., Introducing benzothiazole as corrosion inhibitor for stainless steel. Corros. Sci. 75, 269 (2013).

41. Fouda, A.S. and Ellithy, A.S., Inhibition effect of 4-phenylthiazole derivatives on corrosion of 304L SS in HCl solution. Corros. Sci. 51 (4), 868(2009).

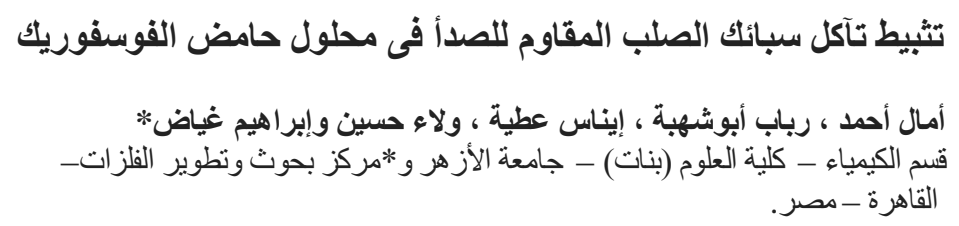

تتاول البحث در اسة تآكل اثثين من سبائك الفو لاذ المقاوم للصدأ في محلول حامض

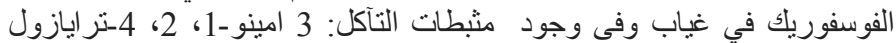

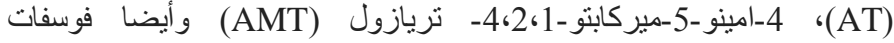

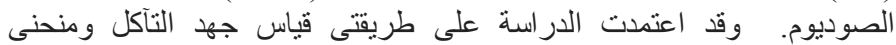
الاستقطاب. وأظهرت قياسات جهد التآكل لأقطاب الفولاذ الماذ المقاوم للصدأ في تركيزات مختلفة من

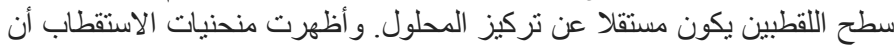
زيادة تركيز

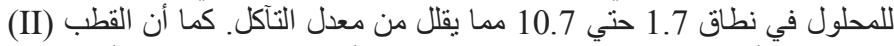

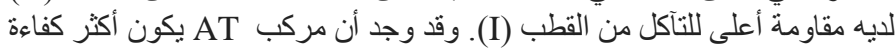

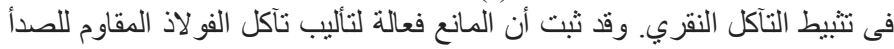

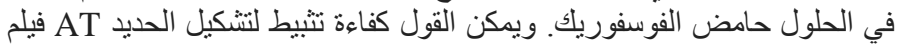
معقد المضغوط على سطح القطب. 
Corrosion Inhibition of Stainless Steel Alloys ...

Egypt. J. Chem. 57, No.1 (2014) 